\title{
Teori Kewirausahaan Bricolage: Lakukan Sendiri untuk Sukses
}

\author{
Agung Purnomo \\ Program Studi Kewirausahaan \\ Universitas Bina Nusantara \\ agung.purnomo@binus.ac.id
}

Studi kewirausahaan di Indonesia kian tumbuh dan berkembang (Purnomo et al., 2019). Entrepreneurship atau kewirausahaan adalah proses kegiatan seorang wirausahawan sebagai orang memulai dan mengelola bisnis dengan mengeksploitasi ide-ide bisnis menjadi peluang yang menguntungkan atau memberi manfaat (Purnomo et al., 2020). Untuk memahami dan mengembangkan pengetahuan kewirausahaan, para ilmuwan melakukan riset dan mengembangkan beberapa teori kewirausahaan.

Salah satu teori kewirausahaan yang berkembang adalah teori kewirausahaan bricolage atau lakukan sendiri (the bricolage theory of entrepreneurship). Kata bricolage berasal dari bahasa perancis yang bermakna lakukan sendiri (do-it-yourself). Teori bricolage digagas oleh Claude Lévi-Strauss pada tahun 1962 yang merupakan seorang antropolog berkebangsaan Perancis. Ini berawal dari upaya Claude guna memperkenalkan konsep kewirausahaan bricolage tatkala ia menunjukkan bahwa orang "biadab" (aborigin) sama-sama melakukan wirausaha seperti orang "beradab". Dia membandingkan tukang (bricoleur) dengan insinyur (engineer) dalam bukunya yang berjudul The Savage Mind. Tidak seperti insinyur, bricoleur akan puas dengan materi yang ada untuk membuat alat apa pun yang dia butuhkan untuk menyelesaikan proyek tertentu saat ia berkembang. Sebaliknya, insinyur merencanakan ke depan, dan mendapatkan akses ke semua yang diperlukan untuk menyelesaikan proyek sebelum memulai. Dengan demikian, bricoleur dipandang kontras dengan pandangan rasional karena proyek diselesaikan dengan memecahkan masalah yang muncul, dengan apa pun yang tersedia daripada apa yang benar-benar dibutuhkan. Para bricoleur mempraktikkan eksperimen coba-coba secara radikal daripada merencanakan ke depan (Lévi-Strauss, 1962).

Teori kewirausahaan bricolage difokuskan pada penjelasan bagaimana kewirausahaan muncul di daerah yang tertekan secara ekonomi, atau daerah miskin sumber daya. Konsep menghasilkan sesuatu dari ketiadaan adalah pendorong utama teori ini. Tidak ada dimaknai dan mengacu pada sumber daya yang kurang dimanfaatkan yang dapat digabungkan kembali menjadi sumber daya produktif. Contoh mesin atau perangkat lunak retrofit yang akan digunakan untuk tujuan yang tidak dimaksudkan, dengan pembuatan pelengkap dan retasan (Baker \& Nelson, 2005). 
Sumber daya yang dimiliki adalah sumber daya yang tersedia di lingkungan wirausahawan. Sehingga, wirausahawan memperoleh dan menggunakan tidak memerlukan usaha besar atau modal yang besar. Pengusaha yang memanfaatkan sumber daya yang ada dipandang sebagai individu yang menolak untuk menerima keterbatasan lingkungan mereka. Sebaliknya, mereka bertindak meskipun ada batasan yang dibangun secara sosial, dan menghindari standar atau definisi tradisional dari masukan yang sah. Teori kewirausahaan bricolage dapat digunakan dalam domain yang berbeda seperti input fisik, sumber daya manusia, pasar, modal manusia, dan kelembagaan. Namun, ada limitasi empiris terhadap penelitian yang mengulas teori bricolage (Laplume \& Yeganegi, 2017).

\section{Referensi}

Baker, T., \& Nelson, R. E. (2005). Creating Something from Nothing: Resource Construction through Entrepreneurial Bricolage. Administrative Science Quarterly, 50(3), 329-366. https://doi.org/10.2189/asqu.2005.50.3.329

Laplume, A., \& Yeganegi, S. (2017). Bricolage Theory of Entrepreneurship. Entrepreneurship Theories. https://entrepreneurshiptheories.blogspot.com/2017/08/levi-strauss-bricolagetheory.html

Lévi-Strauss, C. (1962). La Pensée Sauvage. Plon.

Purnomo, A., Sudirman, A., Hasibuan, A., Sudarso, A., Sahir, S. H., Salmiah, Mastuti, R., Chamidah, D., Koryati, T., \& Simarmata, J. (2020). Dasar-Dasar Kewirausahaan: untuk Perguruan Tinggi dan Dunia Bisnis. Yayasan Kita Menulis.

https://kitamenulis.id/2020/04/06/dasar-dasar-kewirausahaan-untuk-perguruantingi-dan-dunia-bisnis/

Purnomo, A., Usman, I., \& Asitah, N. (2019). Penelitian Kewirausahaan di Indonesia : Pemetaan Publikasi dalam Perspektif Scientometrik (1972-2019). AdBispreneur, 4(3), 207. https://doi.org/10.24198/adbispreneur.v4i3.25021 